Contract No. W-7405-eng-92

\title{
THE MECHANICAL PROPERTIES OF BETA-QUENCHED URANIUM AT ELEVATED TEMPERATURES
}

by

Frederic R. Shober

Lyle L. Marsh

George K. Manning

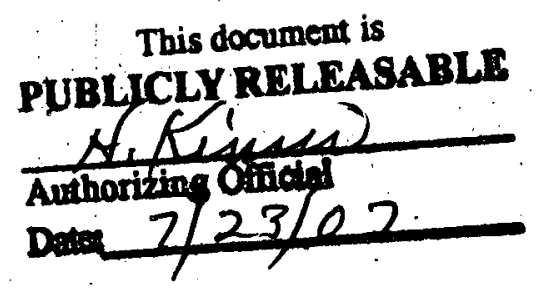

September 6; 1955

Photostat Prices 6.30

Microfilm Prices 3.00

Available from the

Office of Technical Services

Department of Commerce

Washington 25, D.C.

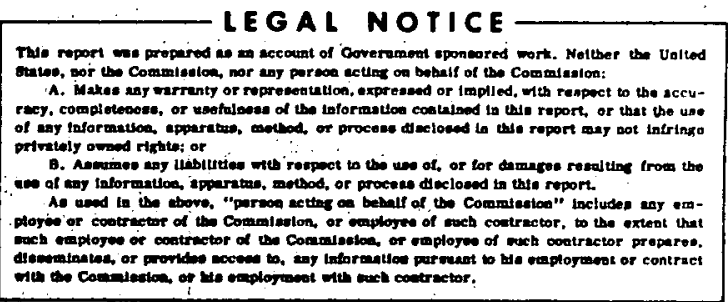

LEGAL NOTICE

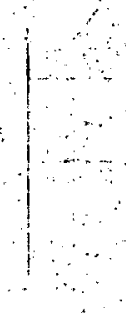

\section{Declassified "with deletions December $1,1959^{\circ}$}

\section{BATTELLE MEMORIAL INSTITUTE}

$505 \mathrm{King}$ Avenue

Columbus 1, Ohio

13 


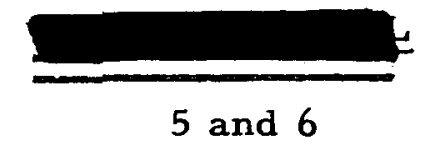

5 and 6

TABLE OF CONTENTS

$\underline{\text { Page }}$

ABSTRACT . . . . . . . . . . . . . . . . . 7

INTRODUCTION . . . . . . . . . . . . . . . . . . 7

TENSILE PROPERTIES AT 28, 300, 500, AND $700 \mathrm{C}$. . . . . . 7

Material and Test Equipment . . . . . . . . . . 7

Results . . . . . . . . . . . . . . . . 8

CREEP PROPERTIES AT 100, 250, 400, AND $500 \mathrm{C}$. . . . . . 11

Materials and Test Equipment . . . . . . . . . . . . 11

Results . . . . . . . . . . . . . . . . 19

Microstructure. . . . . . . . . . . . . . . . . 19

REFERENCES . . . . . . . . . . . . . . . . . 35 


\title{
THE MECHANICAL PROPERTIES OF BETA-QUENCHED URANIUM AT ELEVATED TEMPERATURES
}

\author{
Frederic R. Shober, Lyle L. Marsh, and George K. Manning
}

\begin{abstract}
The creep strength and tensile properties were determined in vacuum for beta-quenched, derby uranium. The stresses to produce a secondary creep rate of 0.0001 per cent per hr at 100,250,400, and $500 . C$ were $48,000,35,500,4,600$, and 1,300 psi, respectively. Ultimate tensile strengths were $114,500,35,100,11,100$, and 8,500 psi at temperatures of $28,300,500$, and $700 \mathrm{C}$, respectively. The creep and tensile strengths decrease quite rapidly with increasing temperature in the temperature range 250 to $400 \mathrm{C}$.
\end{abstract}

\section{INTRODUCTION}

The objective of this study was to provide design engineers with elevated-temperature data on the mechanical properties, particularly creep strength, of beta-quenched uranium. Such data will aid in the analysis of material failures resulting from stress-induced time-dependent deformation.

TENSILE PROPERTIES AT 28, 300, 500, AND $700 \mathrm{C}$

Material and Test Equipment

The uranium was obtained in the beta-quenched condition. 
The as-received bars were approximately 1.5 in. in diameter.

Standard 0.505-in. tensile specimens were machined from the bars. The gage sections were ground and specimens were tested without any additional heat treatment. Only one specimen was tested at each test temperature because of the limited quantity of material.

Elongation was measured by means of SR-4-type strain gages bonded to the specimen gage section. An SR-4 strain-gage indicator was utilized to indicate elongation, which could be read accurately to \pm 0.000005 in. Elongations greater than 1.5 per cent were not obtained because of limitations of the strain gages. Total elongations were measured on all specimens after testing. The crosshead speed for all tests was $0.01 \mathrm{in}$. per min, which corresponds to an approximate strain rate of 0.003 per min.

All specimens tested at elevated temperatures were tested in a specially designed vacuum tank, which contained a resistance-wire-wound furnace, the specimen, and an extensometer. The extensometer was the clip-gage type which measures the elongation of a specimen through a concentric rod-in-tube arrangement. Spring-type clips with strain gages mounted on both surfaces were so constructed that a considerably greater strain range could be obtained from the strain gages. The leads from the gages and the thermocouple leads were brought through the wall of the vacuum tank and attached to the appropriate indicating instruments. The pressure in the vacuum tank was brought to $5 \mu$ of mercury before heat was applied to the specimen. The specimen was brought to the test temperature slowly to allow it to degas and held $1 \mathrm{hr}$ before te ${ }^{\prime \prime}{ }^{\prime} \mathrm{g}$. The temperature was held constant within $\pm 1.5 \mathrm{C}$ during the test.

\section{Results}

The results from the se tests are tabulated in Table 1 and are shown graphically in Figure 1. The tensile strength of alpha uranium decreases quite rapidly with increasing temperature in the range from 28 to $500 \mathrm{C}$. The tensile strengths at 500 and $700 \mathrm{C}$ are quite similar; however, the. elongation at $700 \mathrm{C}$ has been reduced by a factor of 4 compared with the elongation obtained at $500 \mathrm{C}$. The similarity in strength and the decreased ductility can be attributed to the change in crystal structure. The alphato-beta transformation occurs at approximately $654 \mathrm{C}$, the temperature at

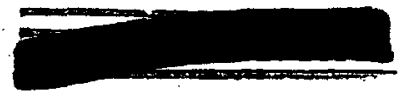


TABLE 1. TENSILE PROPERTIES(a) OF BETA-QUENCHED URANIUM AT 28, 300, 500, AND $700 \mathrm{C}$

\begin{tabular}{|c|c|c|c|c|}
\hline \multirow{2}{*}{$\begin{array}{c}\text { Test } \\
\text { Temperature, } \\
\text { C }\end{array}$} & \multicolumn{2}{|c|}{$\begin{array}{c}\text { Offset Yield } \\
\text { Strength, psi }\end{array}$} & \multirow{2}{*}{$\begin{array}{c}\text { Tensile } \\
\text { Strength, } \\
\text { psi }\end{array}$} & \multirow{2}{*}{$\begin{array}{c}\text { Total } \\
\text { Elongation } \\
\text { in } 2 \text { In. } \\
\text { per cent }\end{array}$} \\
\hline & $\begin{array}{c}0.1 \\
\text { Per Cent }\end{array}$ & $\begin{array}{c}0.2 \\
\text { Per Cent }\end{array}$ & & \\
\hline 28 & 22,000 & 28,000 & 114,500 & 20.4 \\
\hline 300 & 15,300 & 18,500 & 35,100 & 39.8 \\
\hline 500 & 5,300 & 5,800 & 11,100 & 49.0 \\
\hline 700 & 4,800 & 5,600 & 8,500 & 11.6 \\
\hline
\end{tabular}

(a) Strain rate of 0.003 per min. 


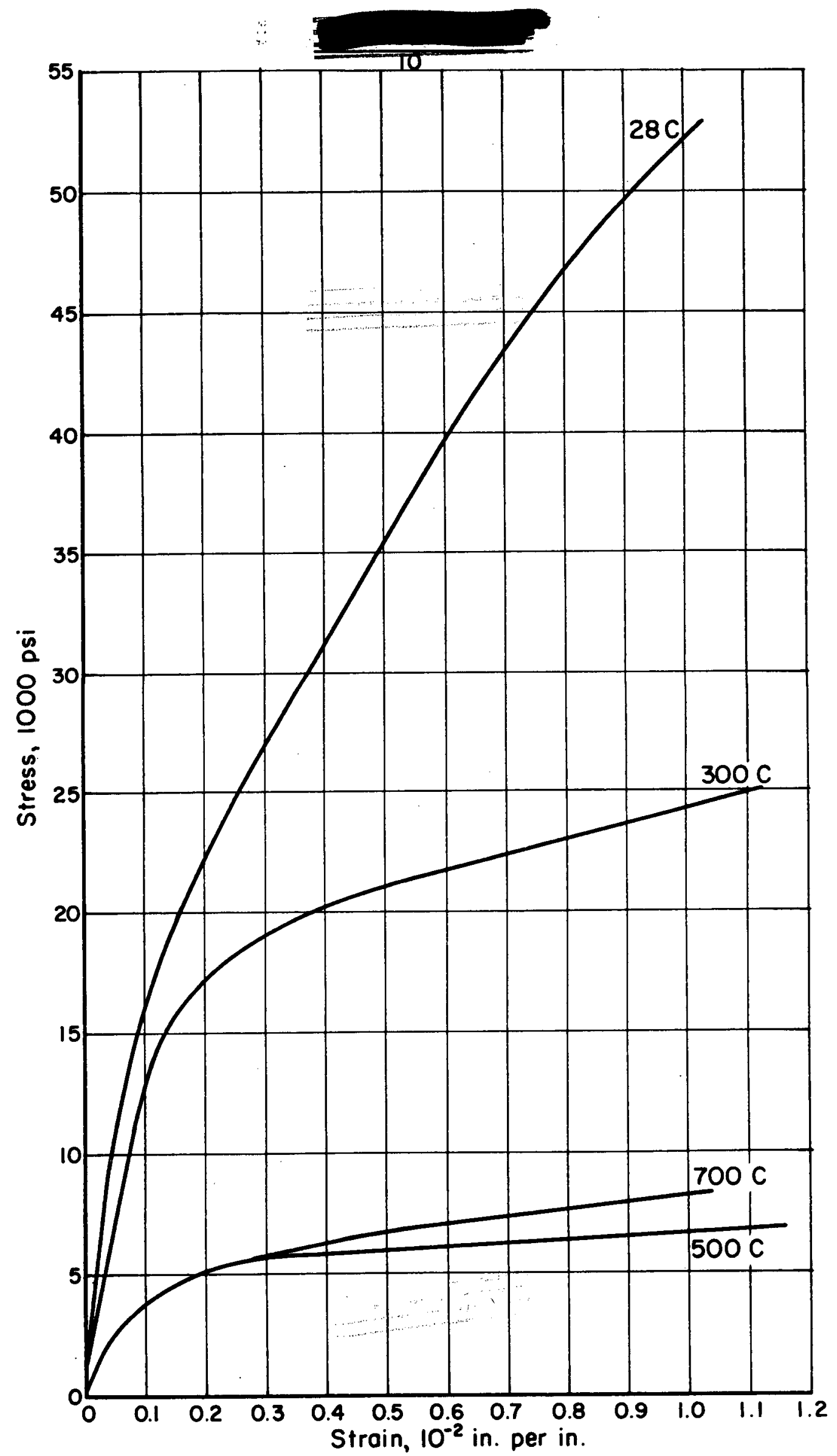

FIGURE I. STRESS VERSUS STRAIN CURVES FOR BETA-QUENCHED URANIUM AT $28,300,500$, AND $700 \mathrm{C}$ 
which the structure changes from an orthorhombic to a complex tetragonal structure.

Hardness of uranium at elevated temperatures, Figure 2, indicates by another test method that the strengths at 500 and $700 \mathrm{C}$ would be similar. The hardness of uranium has been increased nearly fivefold by the transformation process. Greater strength has been achieved by the transformation with a considerable loss in ductility.

\section{CREEP PROPERTIES AT 100, 250, 400, AND $500 \mathrm{C}$}

\section{Materials and Test Equipment}

The material used in creep tests at 100, 250, and $400 \mathrm{C}$ was supplied by HAPO and was cast from unpickled derby uranium. The average composition of the uranium is tabulated below.

\section{Composition, ppm}

\begin{tabular}{|c|c|c|c|c|}
\hline Carbon & Nitrogen & Iron & Silicon & Hydrogen \\
\hline 393 & 56 & 37 & 30 & 1.98 \\
\hline
\end{tabular}

The material was received as 1.5-in.-diameter bars and was subsequently forged at $577 \mathrm{C}$ to 1.125 -in.-square bars. The bars were forged from a helium-atmosphere furnace and water quenched after forging. The forged slugs were rolled to 0.50 -in.-diameter rod from a salt bath at $577 \mathrm{C}$, and then air cooled. The slugs were reduced approximately 88 per cent in rolling. All rolled material was heat treated $1 / 2 \mathrm{hr}$ at $725 \mathrm{C}$ in a salt bath and water quenched. The rods were washed and pickled.

Prior to machining, samples were cut from each end and the center of the bars for room-temperature hardness and grain-size determination. These tests were made to check the uniformity obtained from the heat treatment and quench. The hardness values and grain sizes are shown in Table 2 and Figure 3, respectively. There were only very slight differences in hardness and in grain size, indicating no effective differences in properties from end to end in the as-quenched bars.

Tensile-creep specimens 3 in. long and with 2-in.-long 0.25-in.diameter gage sections were machined from the heat-treated rods. The gage sections of all specimens were surface ground. Testing was done with no additional heat treatment. 

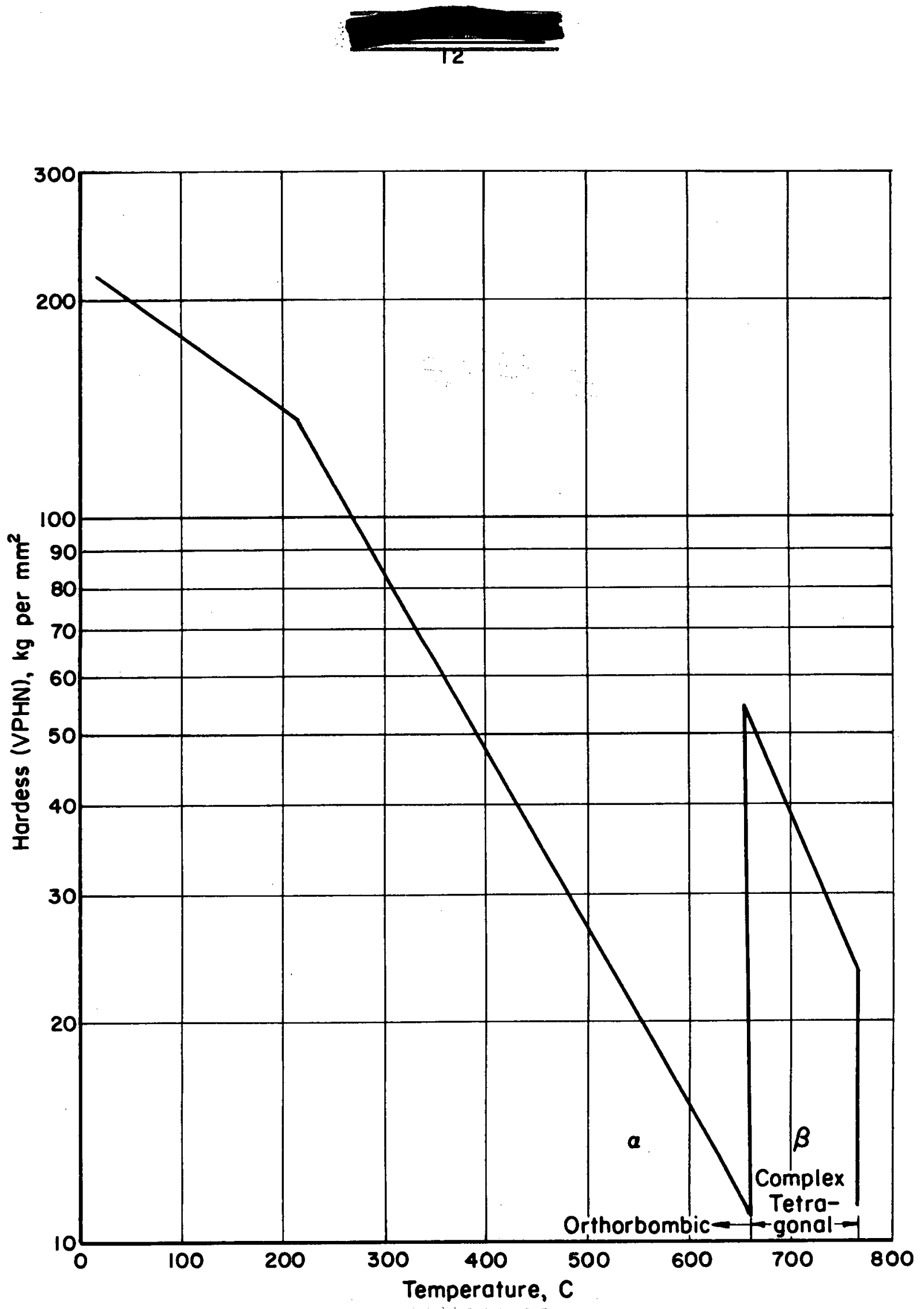

FIGURE 2. HARDNESS OF URANIUM AT ELEVATED TEMPERATURES 
TABLE 2. HARDNESS OF BETA-QUENCHED URANIUM RODS

\begin{tabular}{lcc}
\hline \hline $\begin{array}{l}\text { Rod From } \\
\text { Ingot No. }\end{array}$ & $\begin{array}{c}\text { Portion } \\
\text { of } \\
\text { Rod }\end{array}$ & $\begin{array}{c}\text { Average Hardness } \\
\text { Rockwell A }\end{array}$ \\
\hline M-4481 & End & 55.7 \\
& Center & 55.6 \\
& End & 55.4 \\
M-5427 & End & 54.8 \\
& Center & 54.5 \\
& End & 54.0 \\
M-5039 & End & 54.6 \\
& Center & 55.4 \\
& End & 54.2 \\
\hline
\end{tabular}

(a) Average of five determinations.

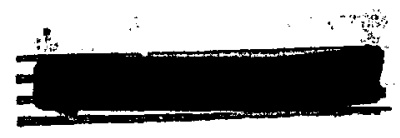



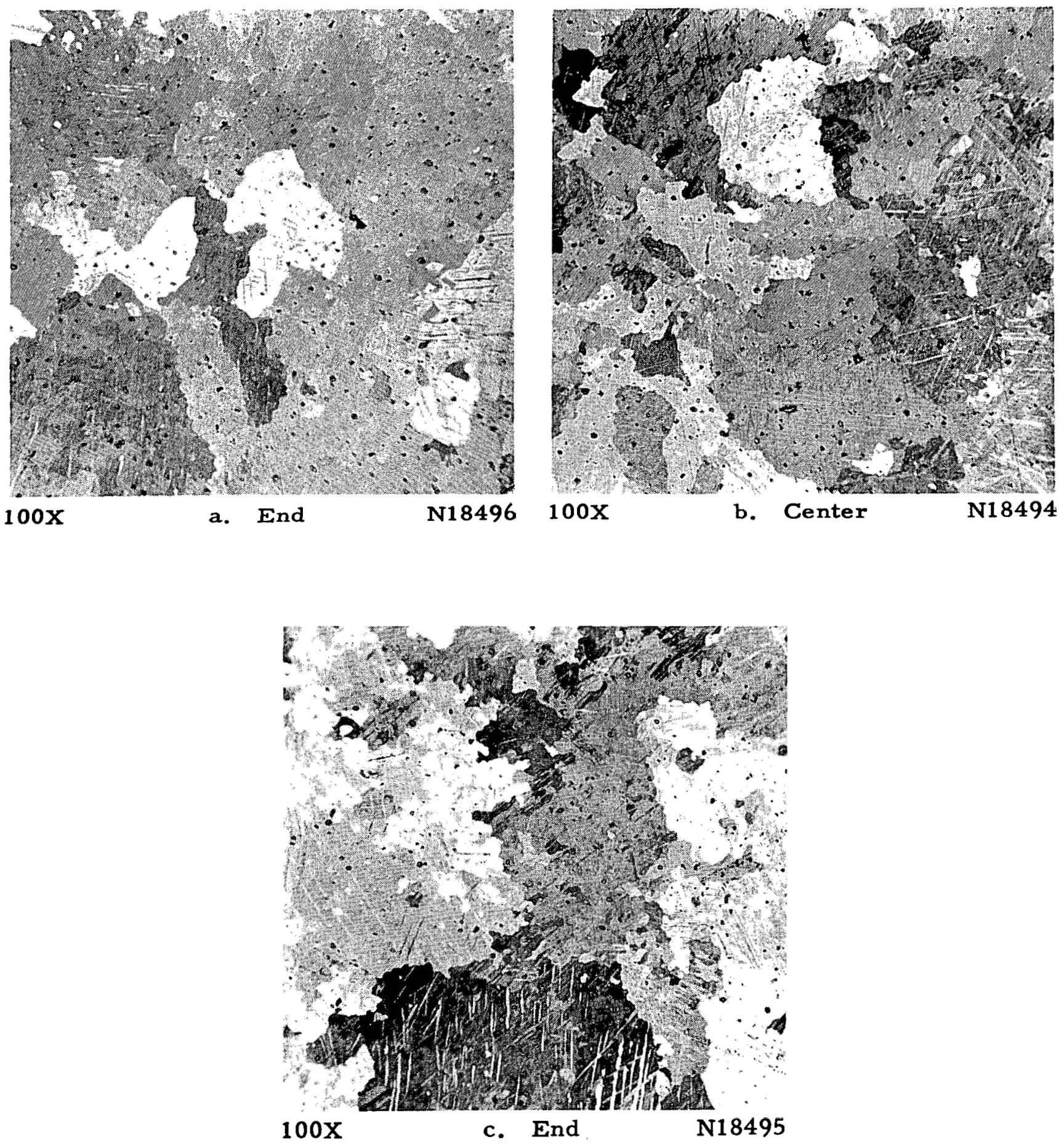

FIGURE 3. MICROSTRUCTURE OF BETA-QUENCHED URANIUM FROM VARIOUS PORTIONS OF ROLLED ROD, INGOT 5039

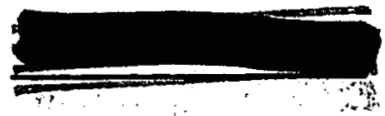


Creep tests at elevated temperatures were conducted in a specially designed vacuum creep unit shown in Figure 4. Each unit is essentially a resistance-wire-wound furnace enclosed in a vacuum chamber. The furnace is surrounded by eight concentric stainless steel radiation shields spaced 0.25 in. apart. Stainless steel baffles placed at the top and bottom of the furnace also help prevent heat loss from the ends of the furnace.

The furnace, reflectors, and baffles are enclosed in the vacuum chamber, which has a bellows arrangement at top and bottom. Figure 5 is an assembly drawing of the components. The grips holding the specimen pass through these bellows and are attached to a fixed frame and a lever arm. The bellows permit deformation of a test specimen without disturbing the vacuum system. The vacuum chamber has small Vycor windows that are diametrically opposed and are aligned with openings in the baffles and furnace tube to provide a means of reading the extensometer attached to the specimen during testing.

The load to produce the desired tensile stress is applied through a 9:1 lever-arm ratio. Provisions are made to balance out any extraneous weight of the testing equipment and to compensate for the loss in load due to the effect of the evacuated bellows. The load was readjusted for tests in which the extension exceeded 2 per cent.

The extension of the specimens during testing was measured by an optical method. The movement of intersliding platinum strips attached to specimens was measured with an optical comparator. Readings were taken at 24-hr intervals, except at the beginning of a test or when the specimen was elongating rapidly. Readings were taken on this group of tests every 10 min for the first hour, and then hourly for the following $8 \mathrm{hr}$. The sensitivity of the optical comparator is $50 \mu$ in.

Test temperatures were held within $\pm 3 / 4 \mathrm{C}$ for tests at $500 \mathrm{C}$ and within $\pm 1 / 2 \mathrm{C}$ for tests at 400,250 , and $100 \mathrm{C}$. A Foxboro controller in combination with an anticipator-type controller circuit maintained these test temperatures. Before a load was applied to a test specimen, the chamber was evacuated to $5 \mu$ of mercury pressure and held at test temperature for $1 \mathrm{hr}$.

The creep specimens tested at $500 \cdot \mathrm{C}$ were prepared from the same material as were the tensile-test specimens and were "triple-dipped" beta quenched. However, one creep test was performed at $500 \mathrm{C}$ and $4500 \mathrm{psi}$ on a specimen of the same material as was used in creep testing at lower temperatures; the specimen was heated $1 / 2 \mathrm{hr}$ at $725 \mathrm{C}$ in a salt bath and water quenched. Creep curves for these two beta-quenched materials are given in Figure 6. The results were only slightly different, but the shape of the early portions of the curve were more noticeably different. It was felt ultimately that there was not sufficient difference between the two to warrant testing of both materials at $500 \mathrm{C}$. 


\section{6}

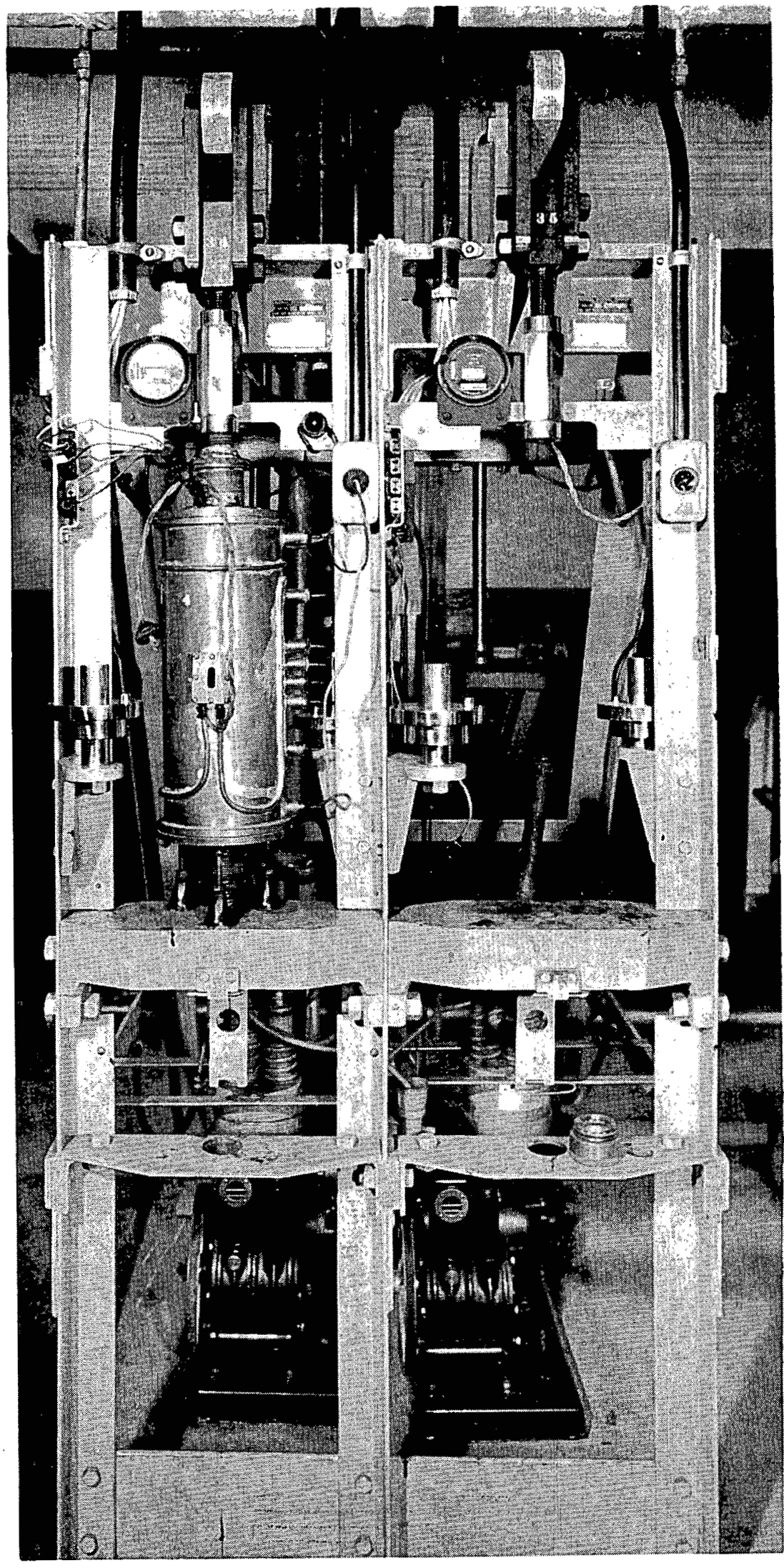

FIGURE 4. VACUUM CREEP UNIT AND ST AND USED FOR ELEVATED-TEMPERATURE TESTS ON BETA-QUENCHED URANIUM 


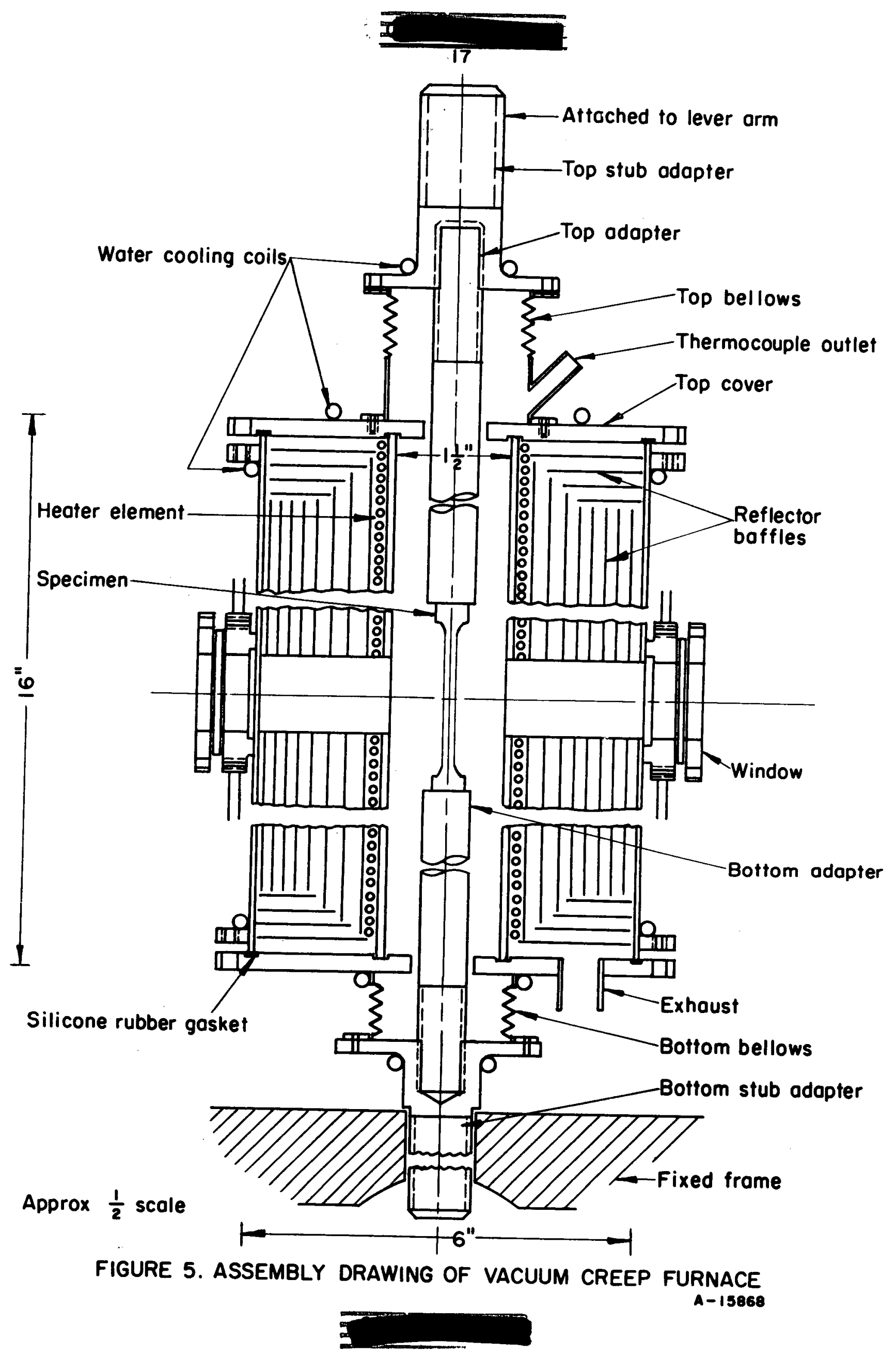




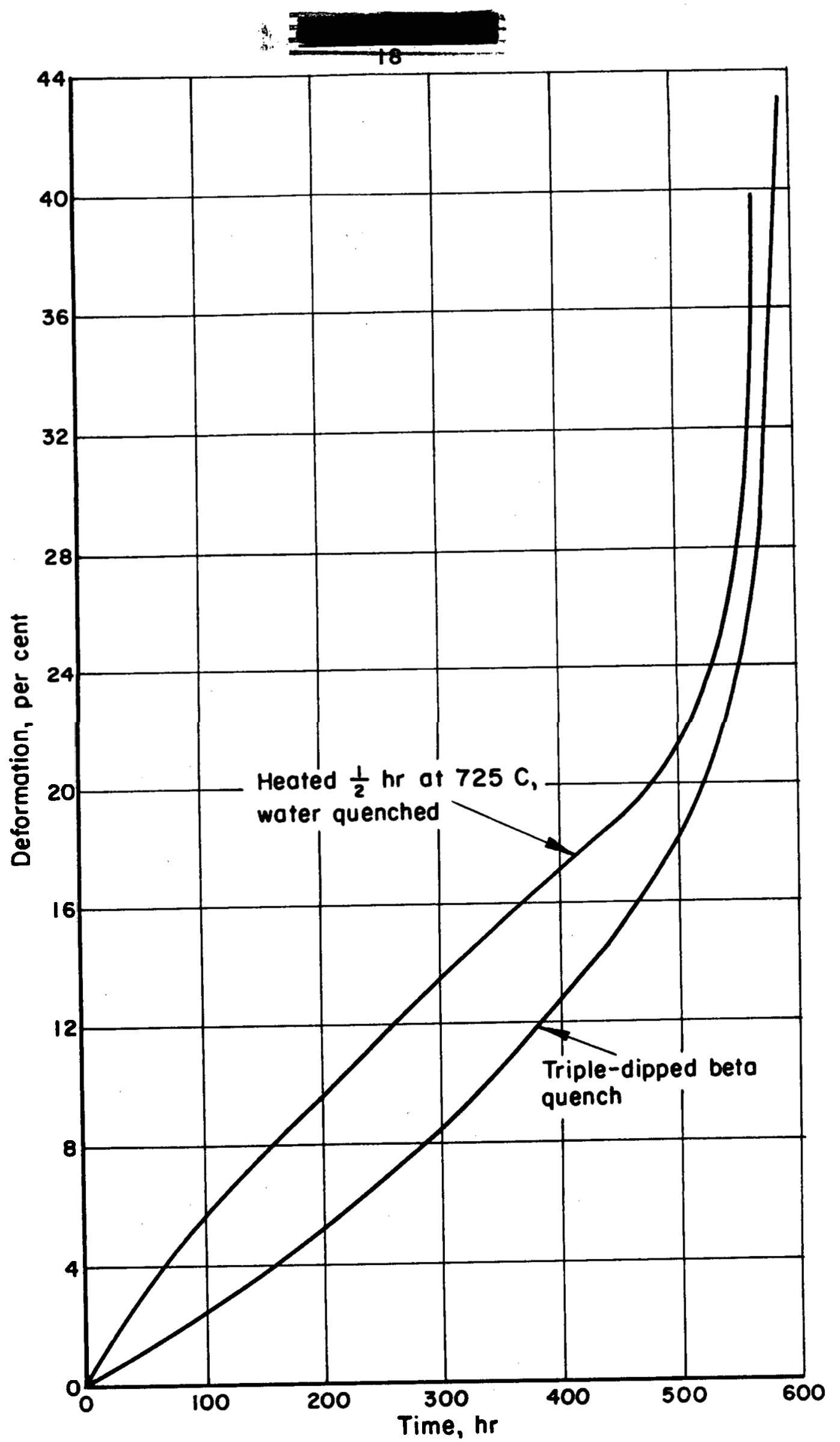

FIGURE 6. A COMPARISON OF CREEP PROPERTIES AT 4500 PSI AND $500 \mathrm{C}$ OF URANIUM BETA QUENCHED BY DIFFERENT PROCEDURES 


\section{Results}

The creep properties of beta-quenched uranium are summarized in Table 3 and in Figures 7 through 18. The deformation versus time curves have been plotted on two time scales to provide a better comparison of data at the short times. The curves in Figure 17 were plotted to show the variance of minimum creep rate with stress at the test temperatures. The slopes of these curves change between 250 and $400 \mathrm{C}$. This change in slope is probably indicative of a change in the dominant creep mechanism.

The relationship between the creep stress and test temperature is more clearly shown in Figure 18. In this figure, the stress to produce some definite secondary creep rate is plotted versus temperature. The stress to produce a definite secondary creep rate begins to decrease more rapidly in the temperature range between 250 and $400 \mathrm{C}$. The inflection points in the curves reflect a change in the mechanism for creep that is, presumably, due to the onset of rapid recovery.

By using the relation $\sigma=f\left(\dot{\epsilon}_{e} \Delta H / R T\right)$ with which J. E. Dorn(1) and associates successfully correlated the creep of aluminum, iron, nickel, copper, zinc, platinum, gold, and lead at elevated temperatures, a value for $\Delta H$ of approximately $52,000 \mathrm{kcal}$ per mole was calculated for temperatures in the range 400 to $500 \mathrm{C}$. In the above relationship $\sigma=$ stress, $\dot{\epsilon}=$ secondary creep rate, $R=$ gas constant, $T=$ absolute temperature, and $\Delta H=$ the activation energy for creep. Dorn also found that for a given metal the $\Delta \mathrm{H}$ value for creep agreed quite well with the activation energy for selfdiffusion. A second correlation reported by Dorn was that there is a linear relationship between the melting temperature of a given metal and the activation energy for self-diffusion. Assuming this to be correct, such a plot predicts a melting temperature for uranium of approximately $1130 \mathrm{C}$ which is very close to the accepted value of $1133 \mathrm{C}(2)$. The calculated value for the activation energy of creep also agrees quite well with the value of 50,000 cal per mole for grain-boundary relaxation determined by internal friction methods reported by R. E. Maringer(3).

\section{Microstructure}

Representative microstructures of as-treated material are shown in Figure 3. This is a typical beta-quenched structure: large grains with smaller grains mixed throughout the structure. The larger grains have some twinned regions.

(1) References at end. 
TABLE 3. CREEP PROPERTIES OF BETA -QUENCHED URANIUM AT 100, 250, 400, AND $500 \mathrm{C}$

\begin{tabular}{|c|c|c|c|c|c|c|c|c|c|c|c|}
\hline \multirow[b]{2}{*}{ Specimen } & \multirow{2}{*}{$\begin{array}{c}\text { Test } \\
\text { Temperature, } \\
\text { C }\end{array}$} & \multirow{2}{*}{$\begin{array}{l}\text { Stress, } \\
\text { psi }\end{array}$} & \multicolumn{5}{|c|}{ Elongation, per cent } & \multirow{2}{*}{$\begin{array}{c}\text { Time } \\
\text { at } \\
\text { Test. } \\
\text { hr }\end{array}$} & \multirow{2}{*}{$\begin{array}{l}\text { Time for } \\
\text { Third-Stage } \\
\text { Creep, } \\
\text { hr }\end{array}$} & \multirow{2}{*}{$\begin{array}{l}\text { Minimum } \\
\text { Creep Rate, } \\
\text { per cent } \\
\text { per br }\end{array}$} & \multirow{2}{*}{$\begin{array}{l}\text { Time Interval } \\
\text { for Secondary } \\
\text { Creep Rate, hr }\end{array}$} \\
\hline & & & On & $100 \mathrm{Hr}$ & $500 \mathrm{Hr}$ & $1000 \mathrm{Hr}$ & Total & & & & \\
\hline $5039-2^{(a)}$ & 100 & 80,000 & 12.00 & - & - & - & 2720 & 8 & 5 & 0.83 & $1-5$ \\
\hline $5039-3^{(a)}$ & 100 & 75,000 & 9.00 & - & - & - & 26.00 & 59 & 32 & 0.16 & $20-32$ \\
\hline $5039-4(a)$ & 100 & 70.000 & 6.35 & 18.30 & - & - & 28.80 & 272 & 85 & 0.034 & $50-85$ \\
\hline $5039-5$ & 100 & 60,000 & 3.30 & 7.40 & 8.80 & 9.35 & 9.36 & 1009 & - & 0.001 & $700-1009$ \\
\hline $5039 \div 6$ & 100 & 50,000 & 1.45 & 2.73 & 3.04 & 3.18 & 3.18 & 1010 & - & 0.00019 & $750-1010$ \\
\hline $4881-1$ & 100 & 40,000 & 0.92 & 1.46 & 1.58 & 1.61 & 1.61 & 1008 & - & 0.00002 & $300-1000$ \\
\hline $4881-2(a)$ & 250 & 50,000 & $\begin{array}{l}\text { Approx. } \\
15.00\end{array}$ & \multicolumn{3}{|c|}{$\begin{array}{l}\text { Ruptured on application of } \\
\text { load }\end{array}$} & 36.00 & - & - & $\cdots$ & 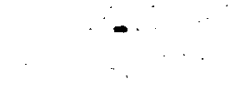 \\
\hline $4881-3^{(a)}$ & 250 & 45,000 & 8.60 & - & - & - & 39.20 & $21 \mathrm{~min}$ & $11 \mathrm{~min}$ & . & $=$ \\
\hline $4881-4(a)$ & 250 & 40.000 & 3.00 & - & - & - & 29.70 & 43.1 & 34 & 0.16 & $25-34$ \\
\hline $4881-12$ & 250 & 37.500 & 2.30 & 10.40 & 12.90 & 14.50 & 14.50 & 1007 & - & 0.0022 & $800-1007$ \\
\hline $4881-11$ & 250 & 35,000 & 0.95 & 1.93 & 2.67 & 3.14 & 3.14 & 1007 & - & 0.00048 & $800-1007$ \\
\hline $4881-5(a)$ & 400 & $\begin{array}{l}20,000 \\
\text { increased to }\end{array}$ & 0.26 & \multicolumn{3}{|c|}{$\begin{array}{l}\text { Ruptured on application of } \\
\mathbf{3 5 , 0 0 0}\end{array}$} & 41.30 & - & - & - & - \\
\hline & & 35,000 & & & & & & $\bullet \quad I$ & & & $\because$ \\
\hline $4881-6(a)$ & 400 & 30,000 & 3.98 & - & - & - & 38.40 & $4 \mathrm{~min}$ & - & $\bullet$ & - \\
\hline $4881-7(a)$ & 400 & 28,400 & 4.08 & - & - & - & 32.40 & $9 \mathrm{~min}$ & - & - & $1 \%$ \\
\hline $4881-8(a)$ & 400 & 23,000 & 0.90 & - & - & - & 30.70 . & 2.5 & 1 & 2.50 & $0.5-1$ \\
\hline $4881-9^{(a)}$ & 400 & 15,000 & 0.52 & 8.80 & - & - & 31.20 & 132 & 25 & 0.043 & $10-25$ \\
\hline $4881-10$ & 400 & 10,000 & 0.075 & 0.70 & 2.51 & 5.80 & 5.80 & 1000 & - & 0.0045 & $250-450$ \\
\hline $4881-13$ & 400 & 8,000 & 0.065 & 0.35 & 1.15 & - & 1.92 & 848 & - & 0.0020 & $200-848$ \\
\hline $5039-1^{(a)}$ & 500 & 4,500 & 0.10 & 7.90 & 21.2 & - & 39.45 & 565 & 480 & 0.026 & \\
\hline HS-5(a) & 500 & 5,500 & 0.04 & 8.25 & - & - & 35.00 & 152 & 25 & 0.041 & $15-25$ \\
\hline HS-4(a) & 500 & 4,500 & 0.07 & 2.42 & 18.00 & - & 42.60 & 591 & 100 & 0.024 & $50-100$ \\
\hline HS - 7 (a) & 500 & 3,500 & 0.015 & 1.20 & 7.00 & 26.50 & 39.00 & 1134 & 150 & 0.009 & $50-150$ \\
\hline HS $-6^{-t}$ & 500 & 3,000 & 0.03 & 0.74 & 3.20 & 7.20 & 7.80 & 1077 & - & 0.0058 & $50-400$ \\
\hline HS-2' & 500 & 2,500 & 0.02 & 0.43 & 1.30 & 2.22 & 425 & 2200 & - & 0.0019 & $1500-2200$ \\
\hline HS-1 & 500 & 2,000 & 0.04 & 0.24 & 0.50 & 0.75 & 1.70 & 2300 & - & 0.0006 & $1000-2300$ \\
\hline
\end{tabular}

Note: Specimens rolled at $577 \mathrm{C}$, held $1 / 2 \mathrm{hr}$ at $725 \mathrm{C}$, and water quenched, except where noted by Footnote (b).

(a) Ruptured during test.

(b) Rolled at $575 \mathrm{C}$, held $85 \mathrm{sec}$ at $735 \mathrm{C}$ and 30 to $40 \mathrm{sec}$ at $595 \mathrm{C}$, water quenched. 


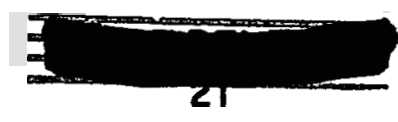

$\Theta$

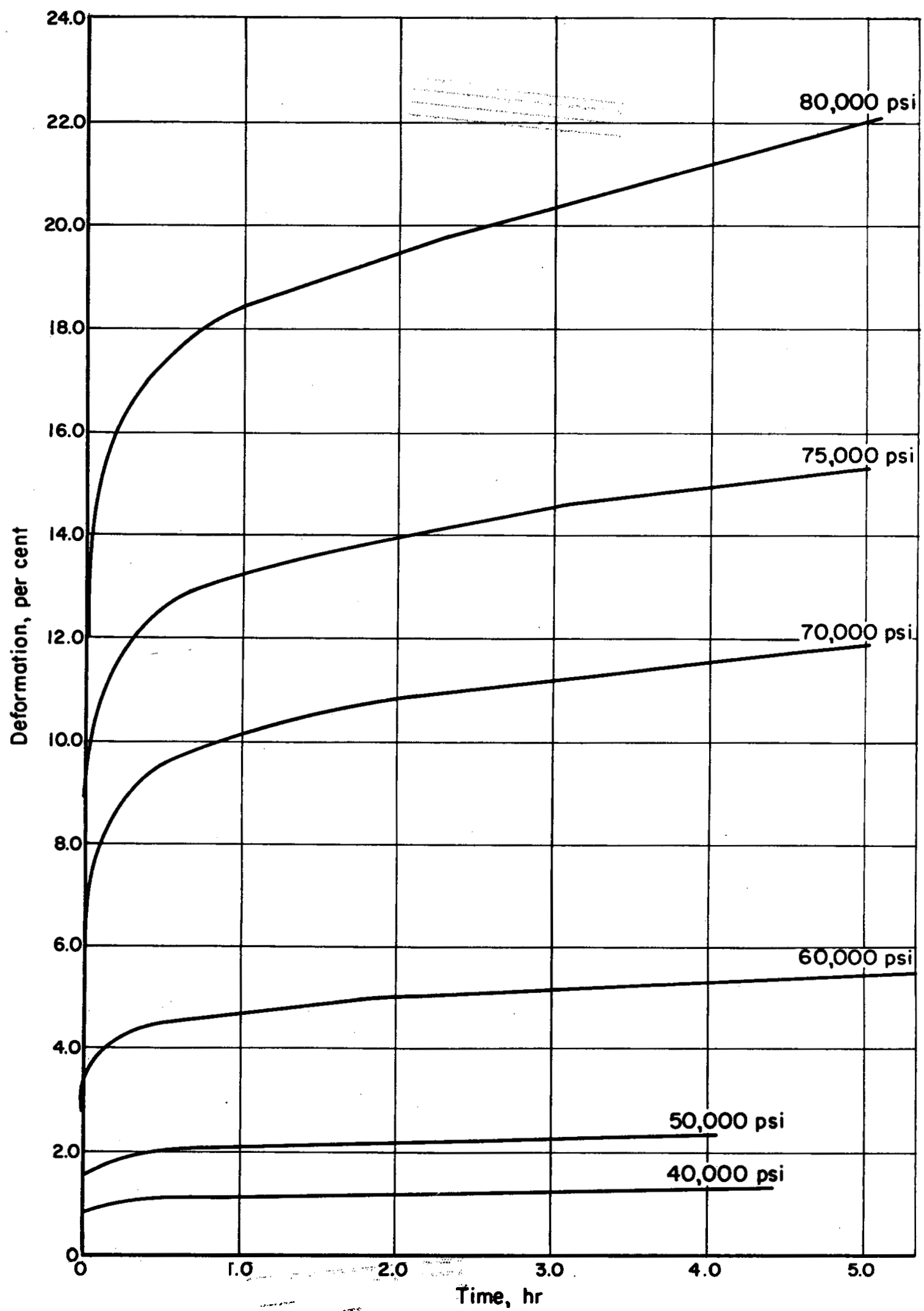

FIGURE 7. DEFORMATION-TIME CURVES FOR BETA-QUENCHED URANIUM AT $80,000,75,000,70,000,60,000,50,000$, AND 40,000 PSI AND $100 \mathrm{C}$ 


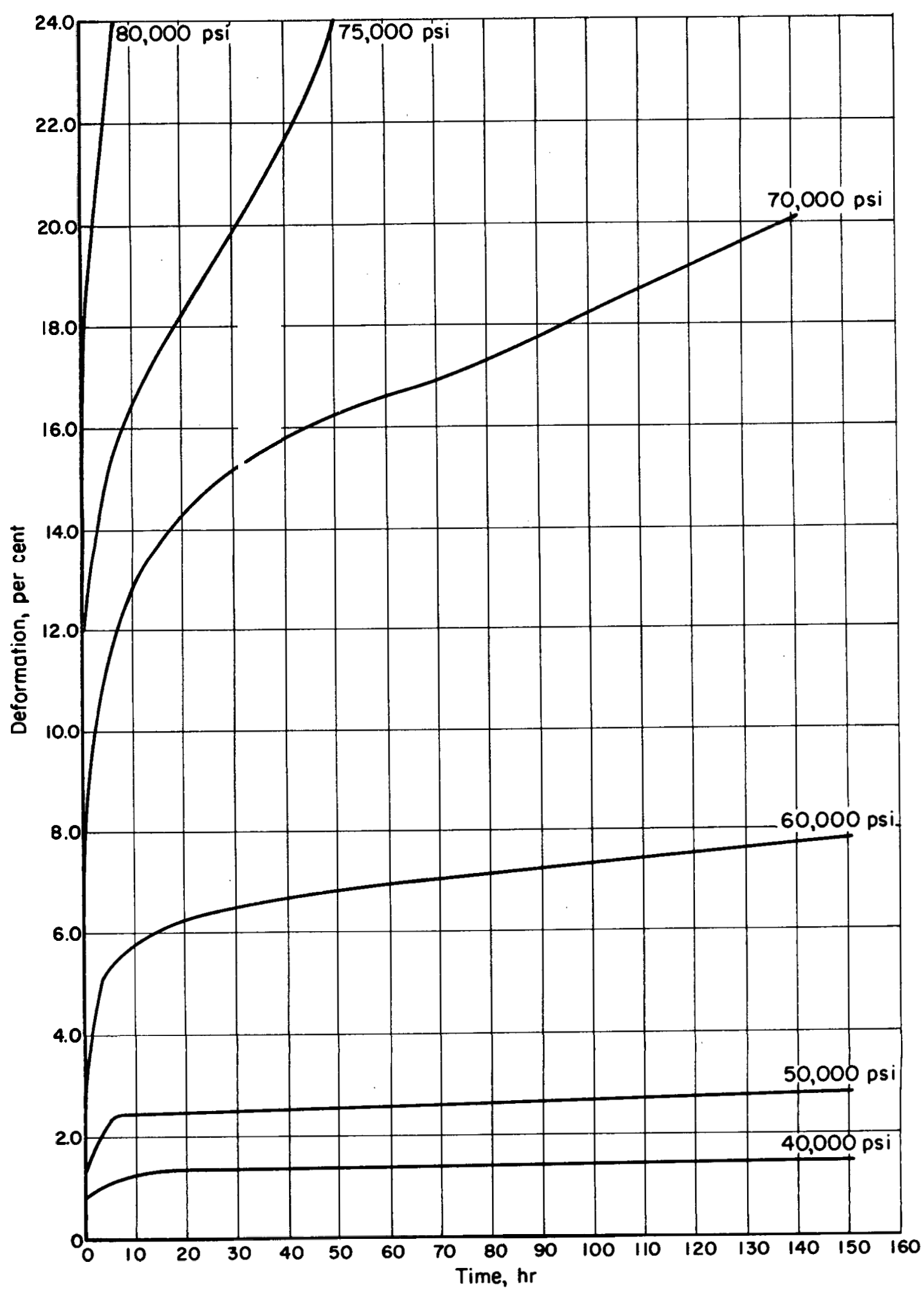

FIGURE 8. DEFORMATION-TIME CURVES FOR BETA-QUENCHED URANIUM AT $80,000,75,000,70,000,60,000,50,000$, AND 40,000 PSI AND $100 \mathrm{C}$ 

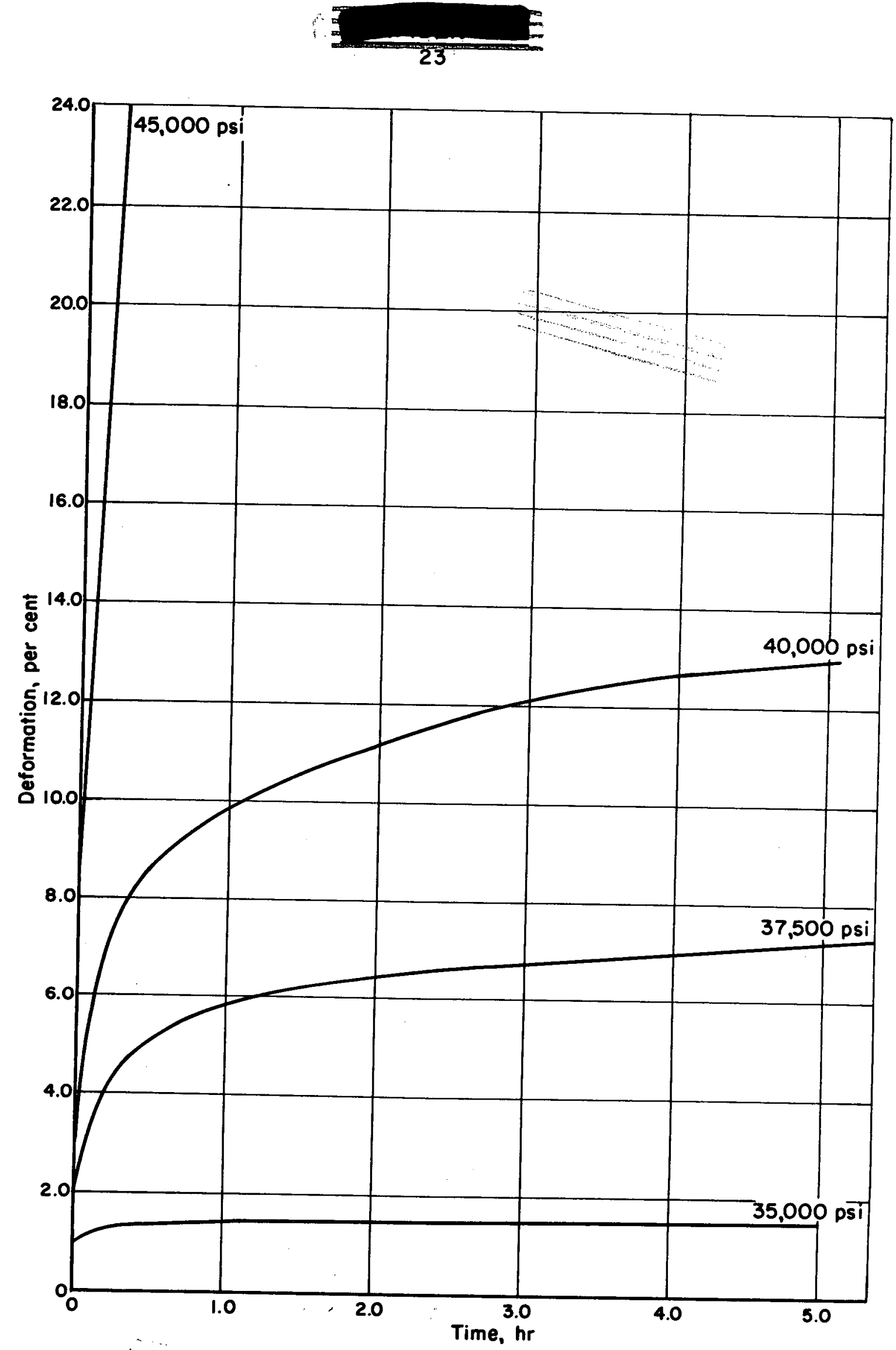

FIGURE 9. DEFORMATION-TIME CURVES FOR BETA-QUENCHED URANIUM AT 45,000,40,000,37,500, AND 35,000 PSI AND $250 \mathrm{C}$ 

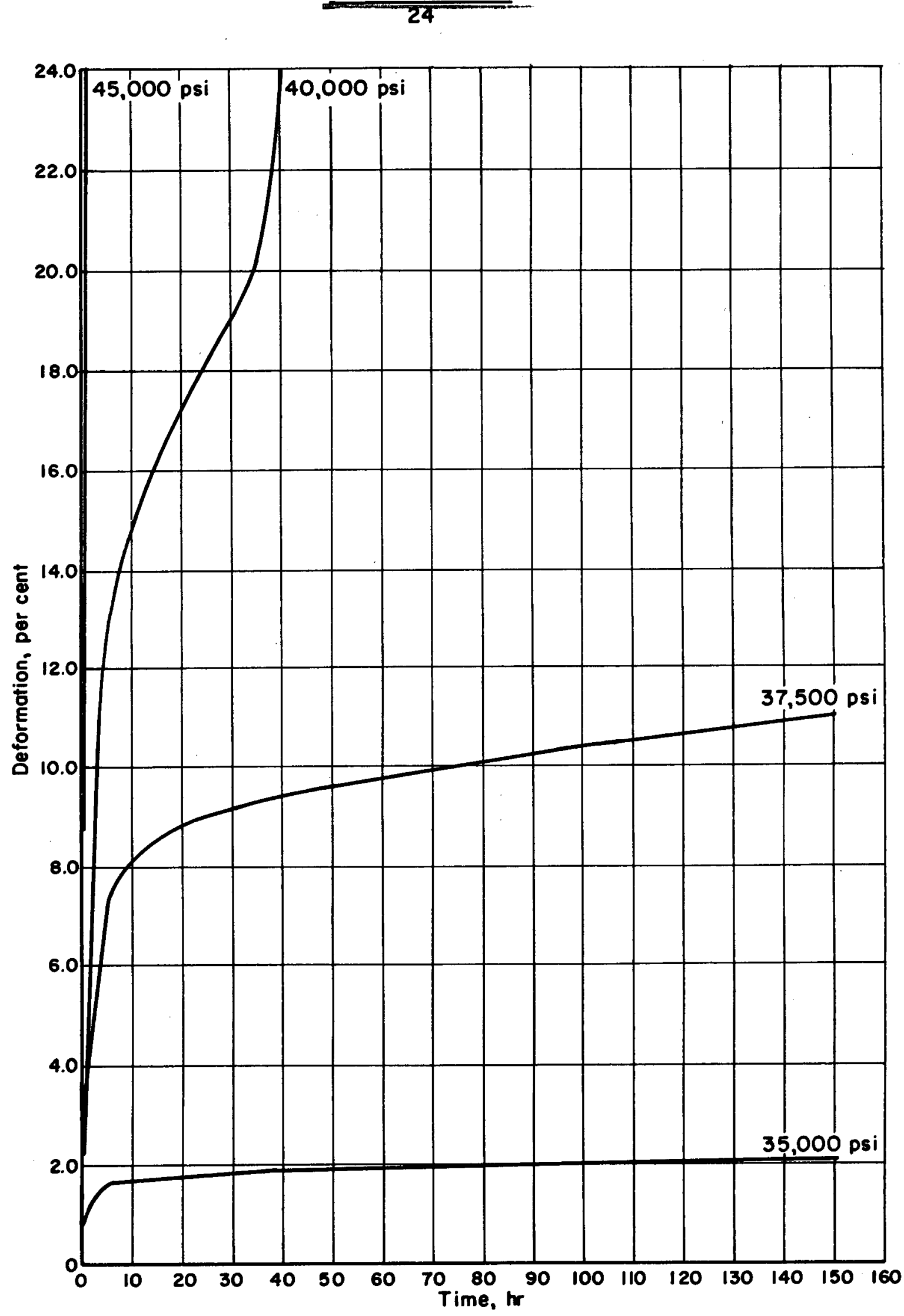

FIGURE 10. DEFORMATION-TIME CURVES FOR BETA-QUENCHED URANIUM AT $45,000,40,000,37,500$, AND 35,000 PSI AND $250 \mathrm{C}$ 


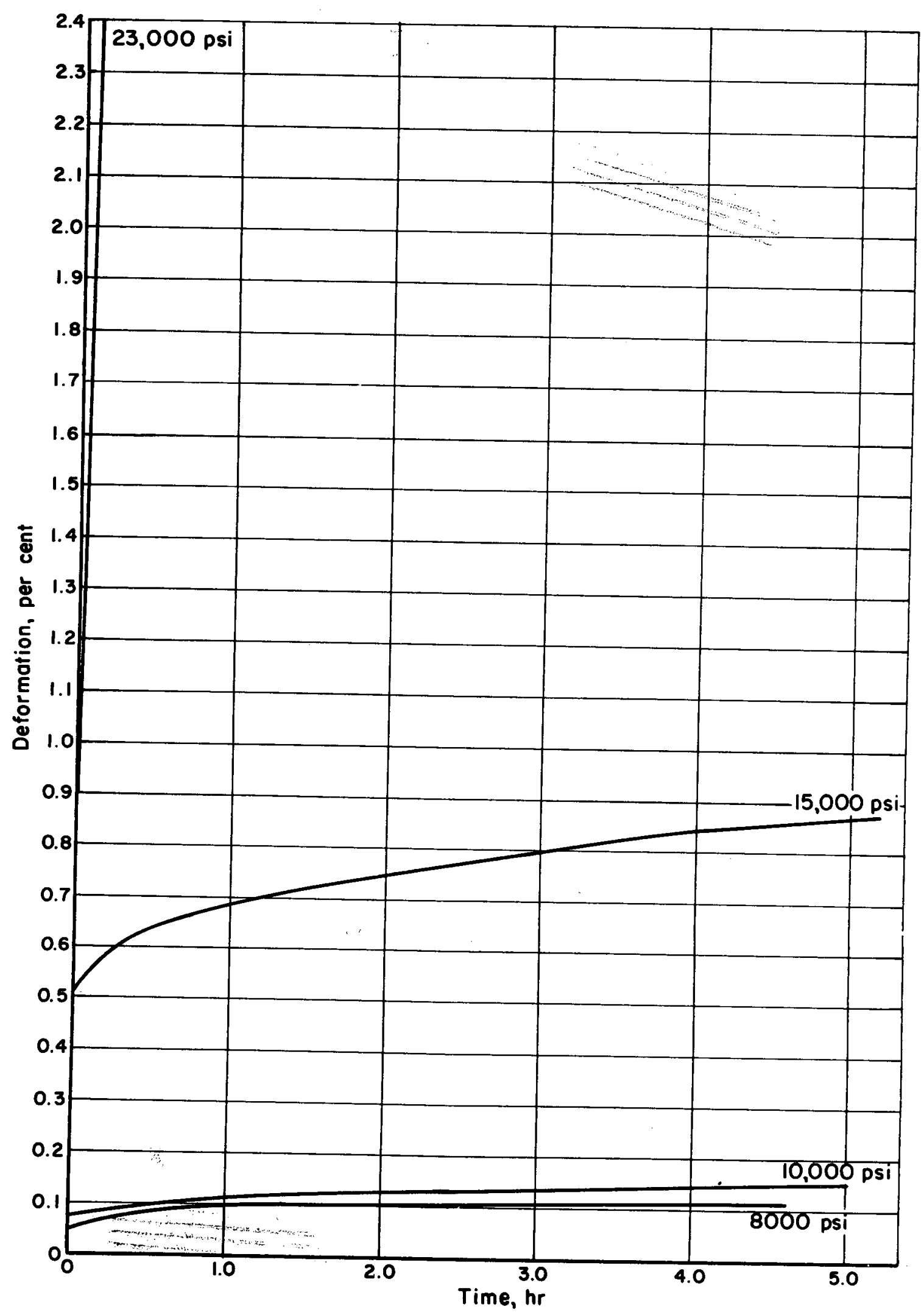

FIGURE II. DEFORMATION-TIME CURVES FOR BETA-QUENCHED URANIUM AT $23,000,15,000,10,000$. AND 8000 PSI AND $400 \mathrm{C}$ 

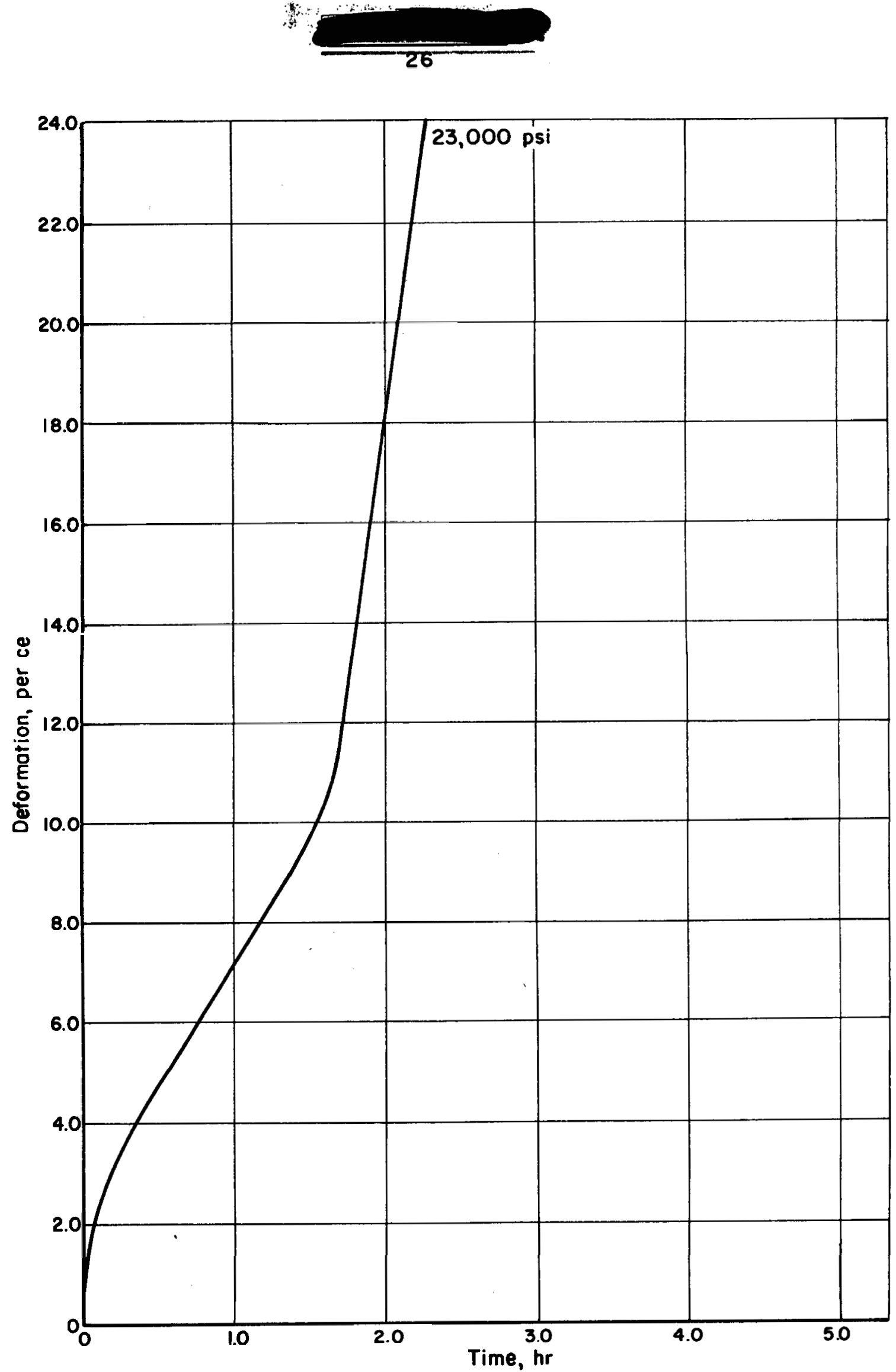

FIGURE 12. DEFORMATION-TIME CURVE FOR BETA-QUENCHED URANIUM AT 23,000 PSI AND $400 \mathrm{C}$ 

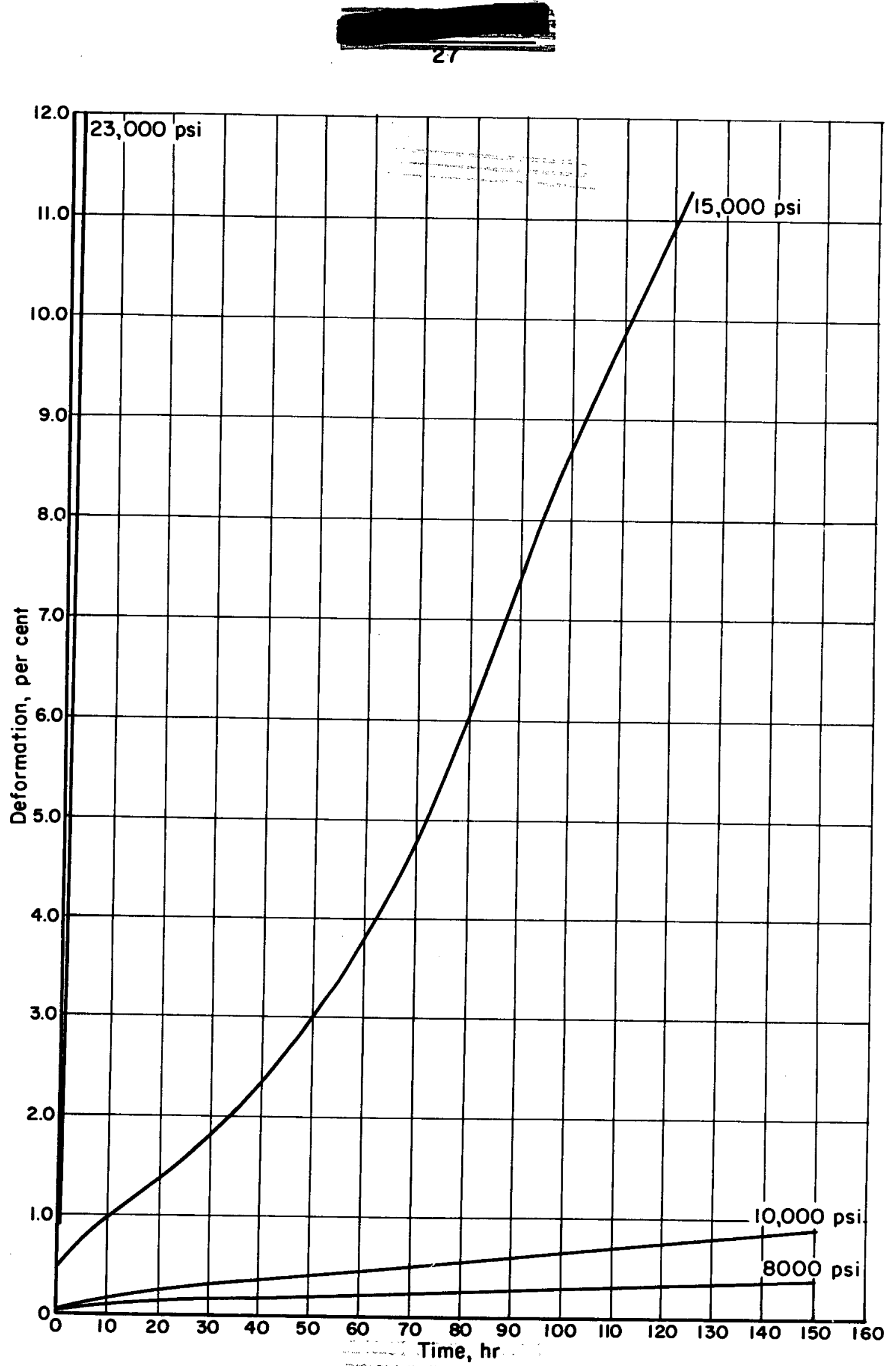

FIGURE 13. DEFORMATION-TIME CURVES FOR BETA-QUENCHED URANIUM AT $23,000,15,000,10,000$, AND 8000 PSI AND $400 \mathrm{C}$ 


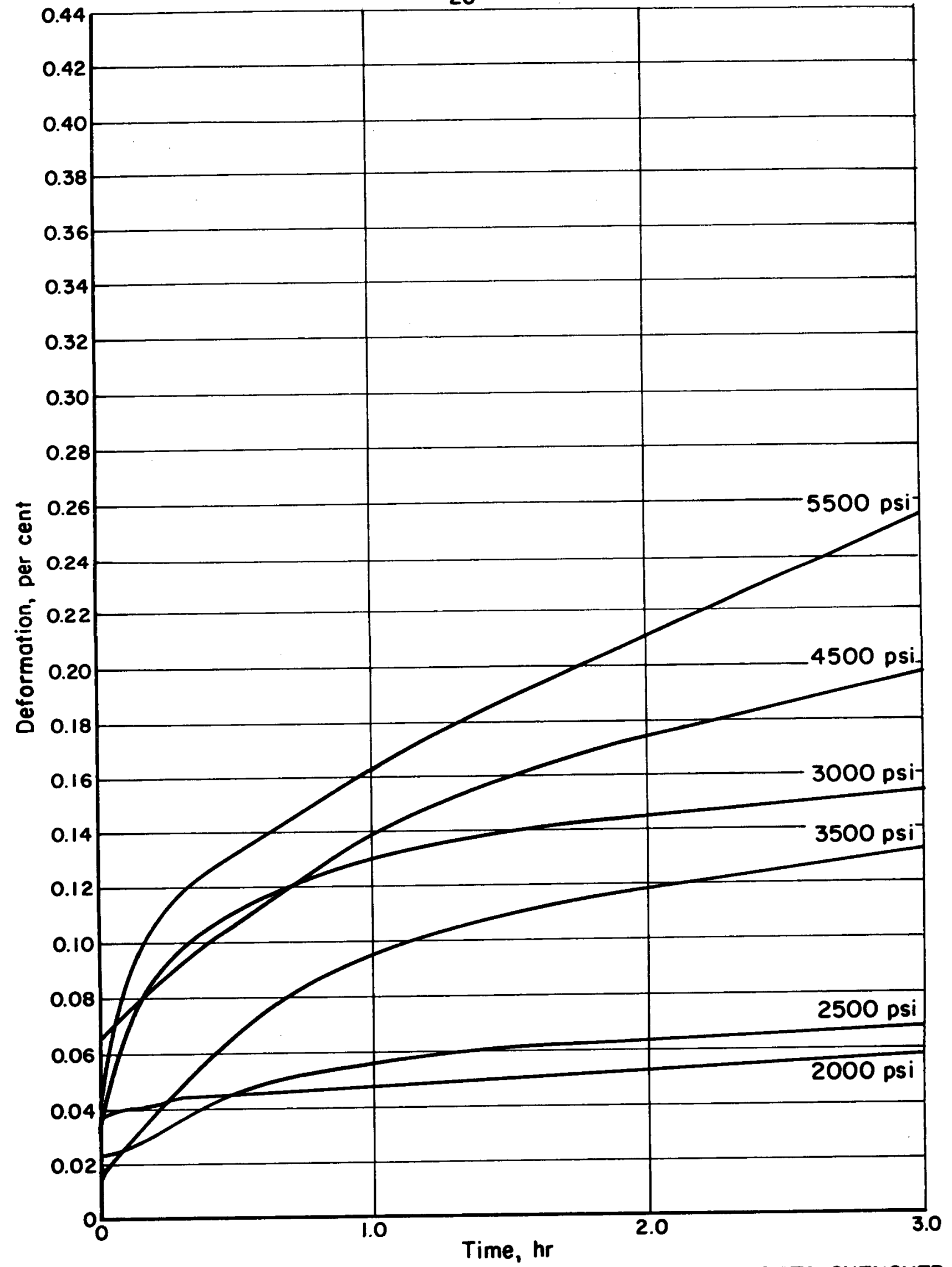

FIGURE 14. DEFORMATION-TIME CURVES FOR TRIPLE-DIPPED BETA-QUENCHED URANIUM AT 5500,4500, 3500, 3000, 2500, 2000 PSI AND $500 \mathrm{C}$ 


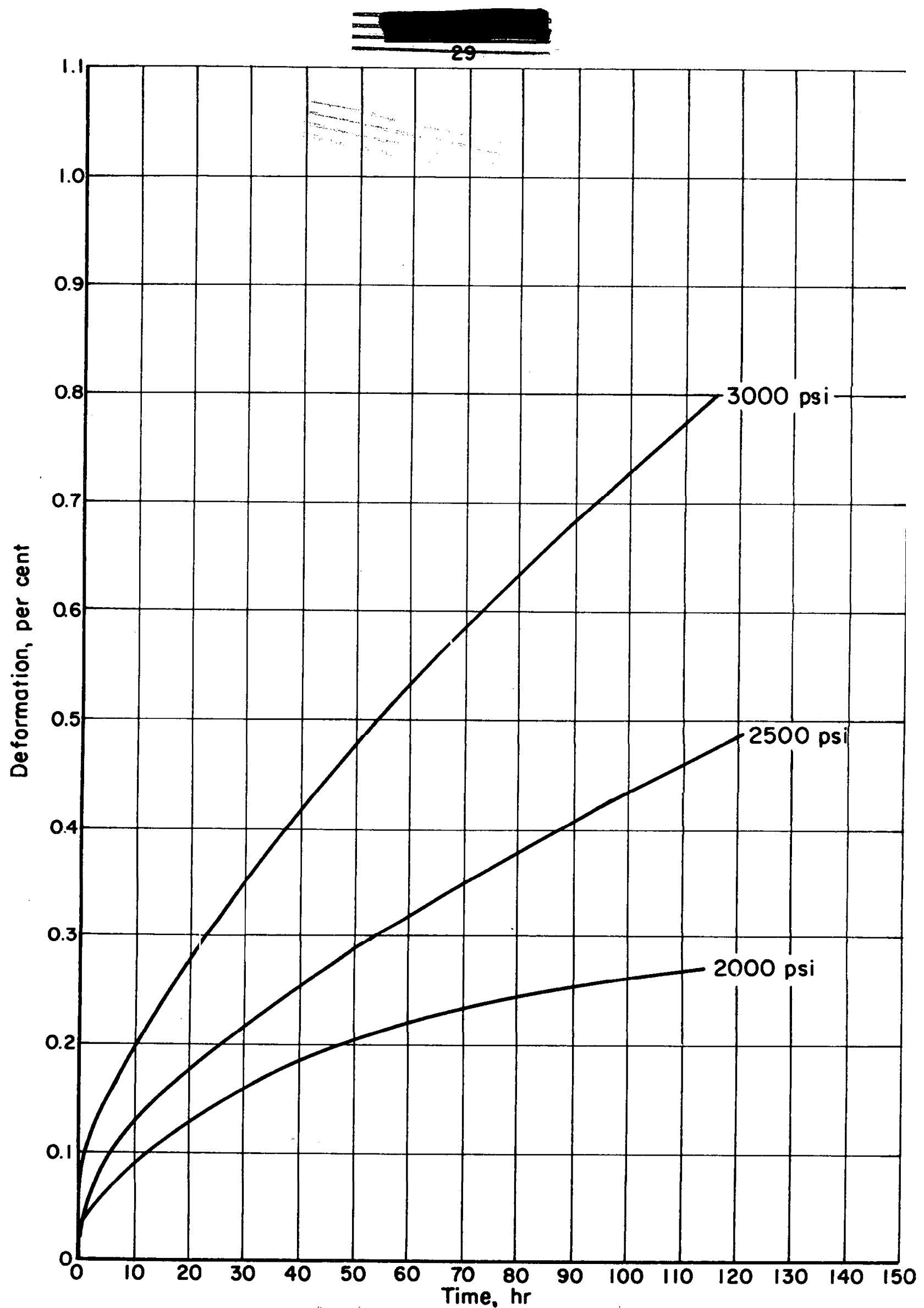

FIGURE 15. DEFORMATION-TIME CURVES FOR HANFORD TRIPLE-DIPPED BETAQUENCHED URANIUM AT 3000, 2500, AND 2000 PSI AND $500 \mathrm{C}$ 

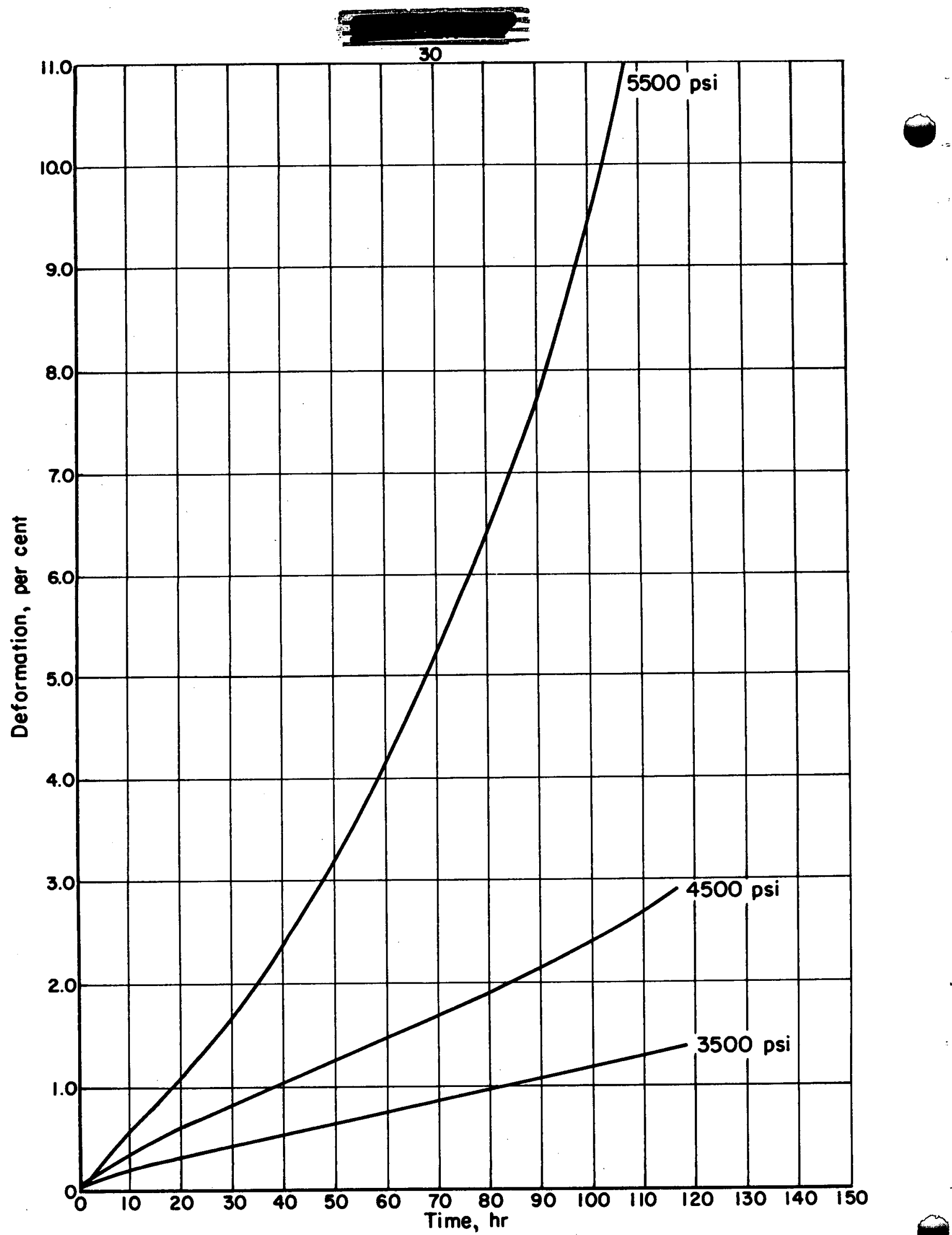


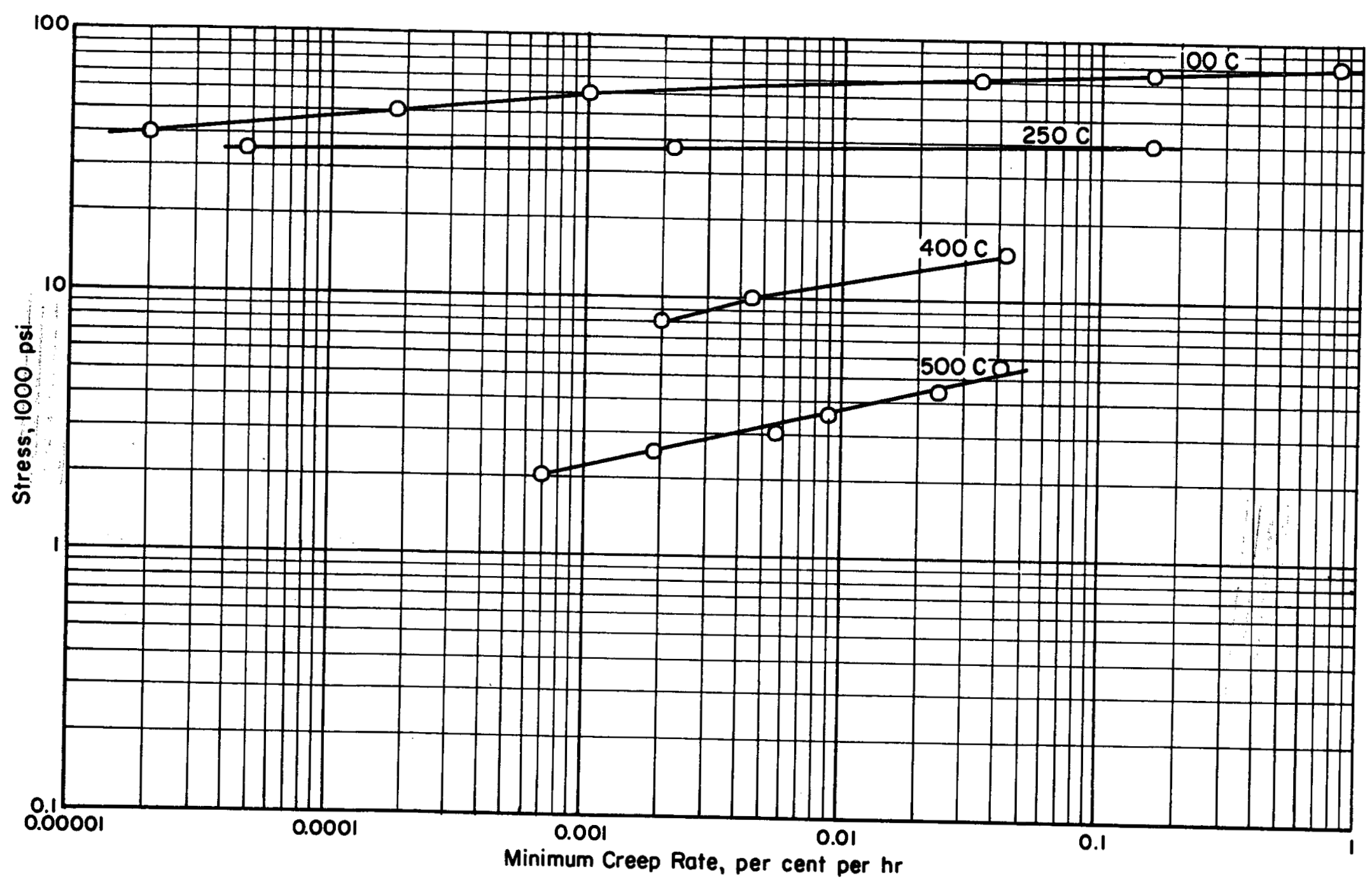
FIGURE 17. RELATIONSHIP BETWEEN CREEP STRESS AND CREEP RATE AT 100, 250, 400, AND
$500 \mathrm{C}$ 

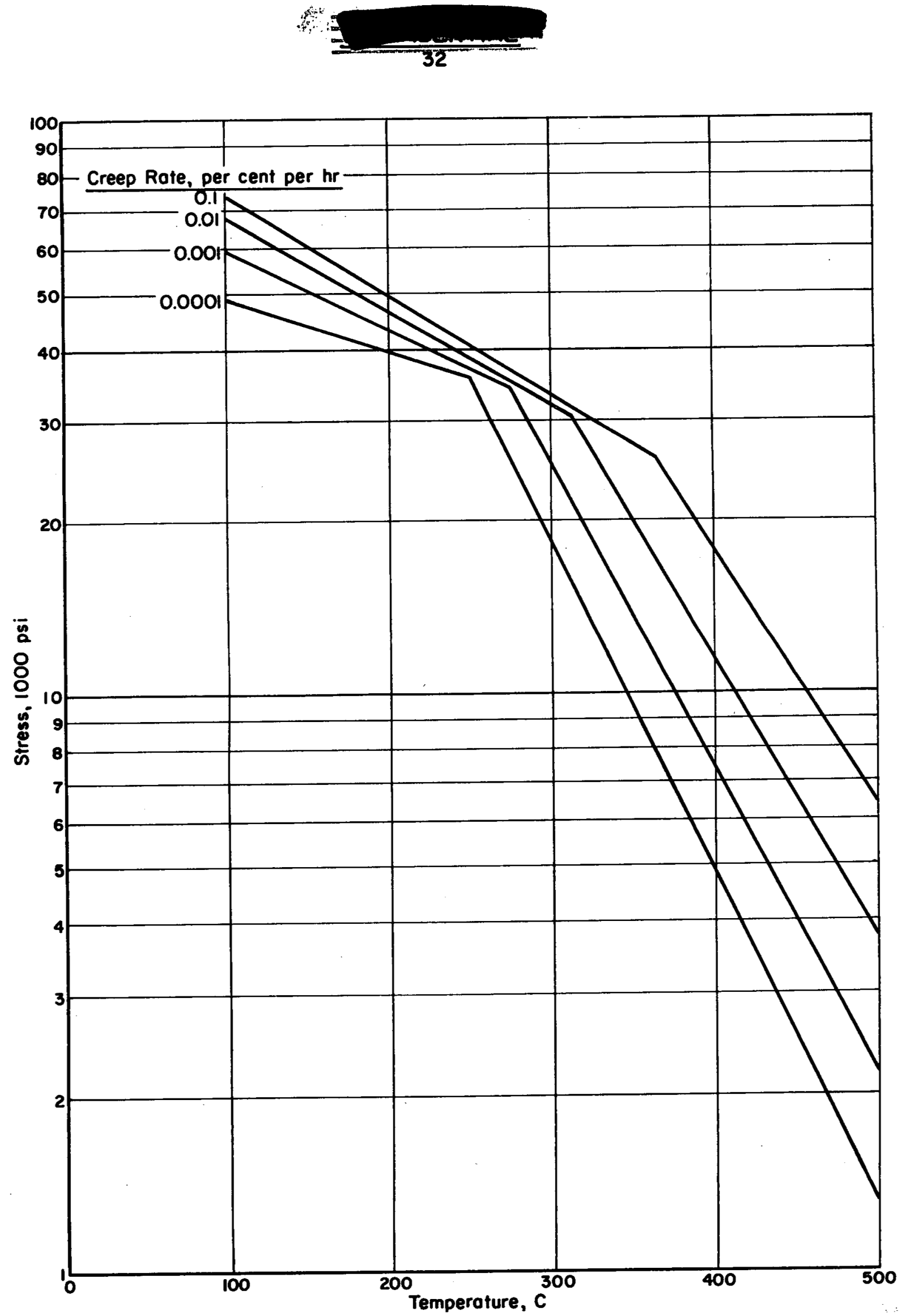

FIGURE 18. RELATIONSHIP BETWEEN CREEP STRESS AND TEMPERATURE FOR BETA-QUENCHED URANIUM IN THE TEMPERATURE RANGE 100 TO $500 \mathrm{C}$ 


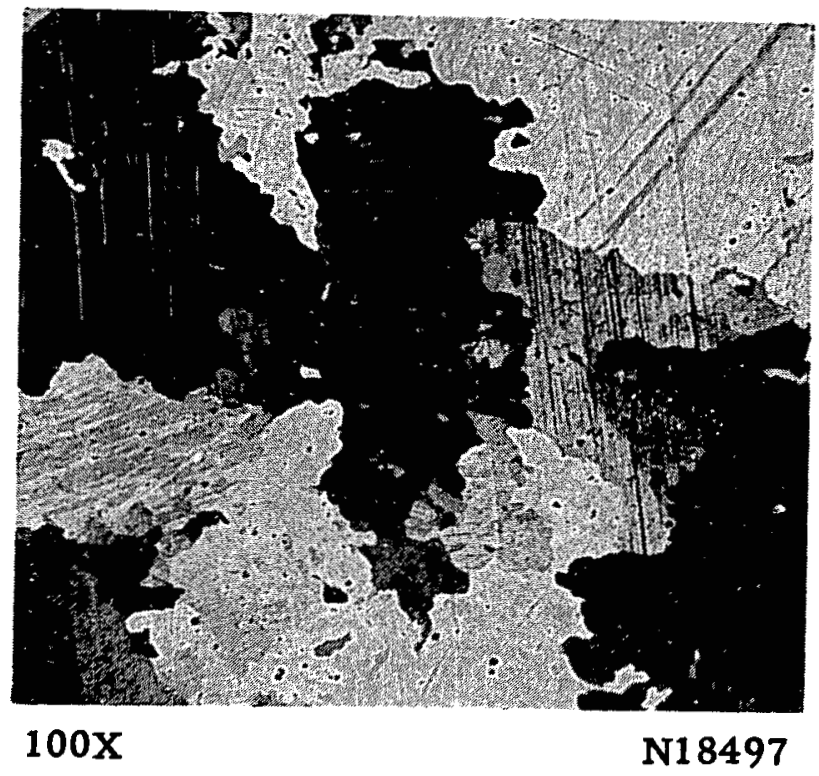

FIGURE 19. MICROSTRUCTURE AFTER TESTING AT 40, 000 PSI AND $100 \mathrm{C}$

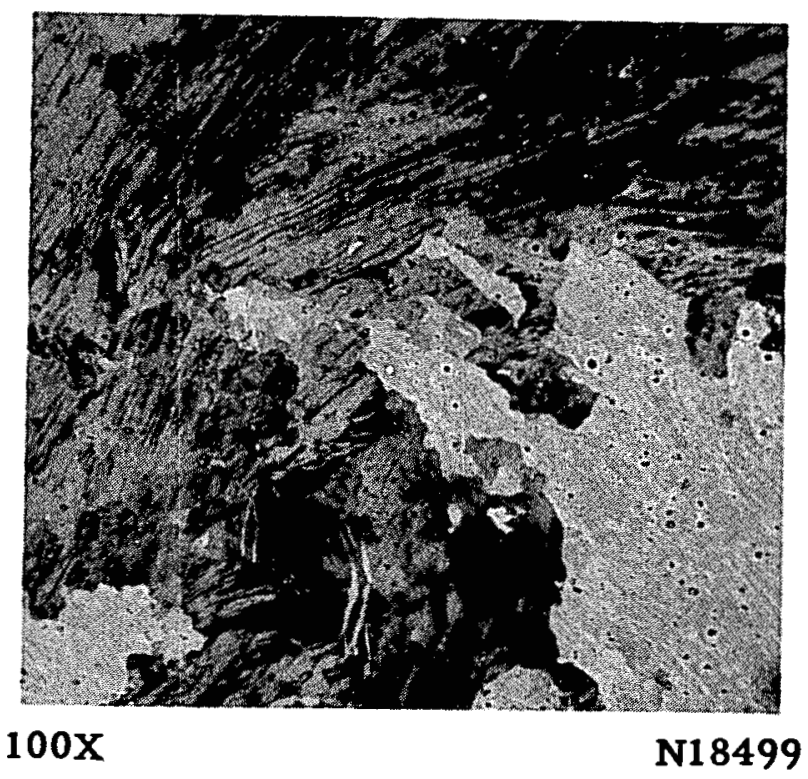

FIGURE 20. MICROSTRUCTURE AFTER TESTING AT 50,000 PSI AND $250 \mathrm{C}$

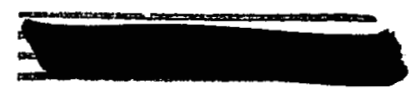




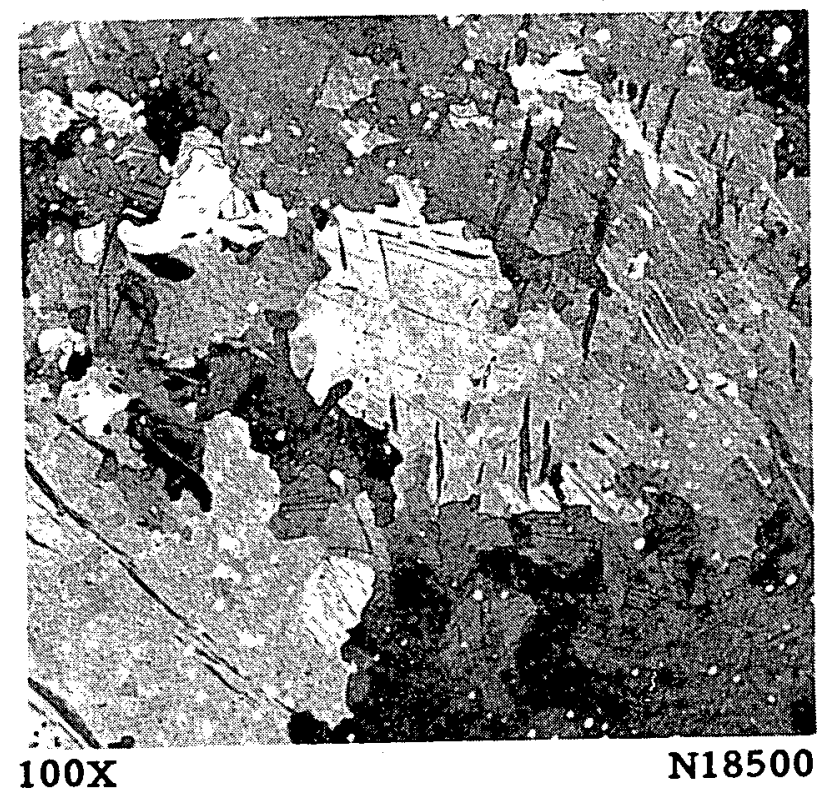

FIGURE 21. MICROSTRUCTURE AFTER TESTING AT 10,000 PSI AND $400 \mathrm{C}$

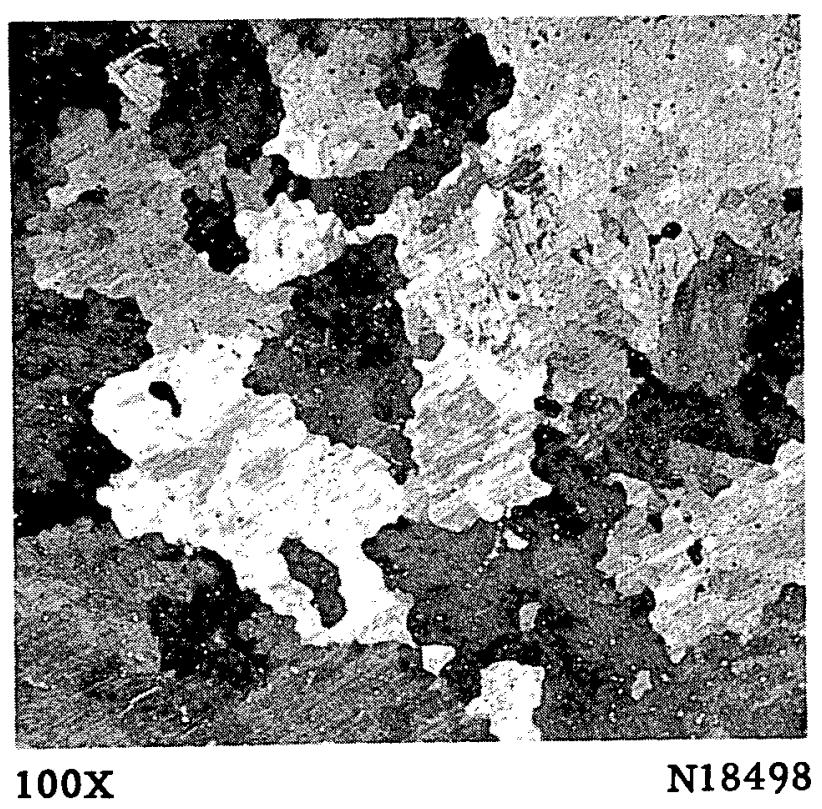

FIGURE 22. MICROSTRUCTURE AFTER TESTING AT 4500 PSI AND $500 \mathrm{C}$

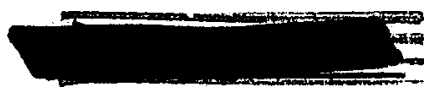


Figures 19, 20, 21, and 22 are representative microstructures of uranium in the as-tested condition. The microstructures of the as-tested materials could be described as generally falling in the following categories:

(1) Figure 19, moderately twinned structure

(2) Figure 20, severely twinned structure

(3) Figure 21, twin growth and grain-fragmented structure

(4) Figure 22, grains breaking up to form small equiaxed grains.

There did not appear to be any correlation between microstructure and test temperature, total deformation or time at test.

\section{REFERENCES}

(1) Sherby, O. D., Orr, R. L,, and Dorn, J. E., "Creep Correlations of Metals at Elevated Temperatures", Trans. AIME, Journal of Metals, 71-80 (January, 1954).

(2) The Reactor Handbook, Vol. 3, (April, 1953), "Materials", p 437. SECRET

(3) Maringer, R. E., Johnson, R. D., and Manning, G. K., "Dimensional Stability of Uranium", Proceedings of AEC Information Meeting, (April, 1955). SECRET

FRS:LLM:GKM/mm 